\title{
Linguistic Awareness of the Prepositional Phrase Complexities in the English as a Foreign Language Context
}

\author{
Conocimiento lingüístico de las complejidades de las frases preposicionales en el contexto \\ del Inglés como Lengua Extranjera
}

\section{Conhecimento lingüístico das complexidades das frases preposicionais no contexto do inglês como língua estrangeira}

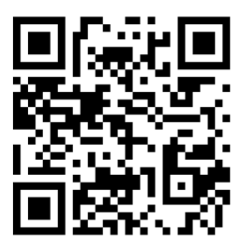

Chinger Enrique Zapata-Leal

Universidad Católica del Norte

Antofagasta, Chile

czapata@ucn.cl

https://orcid.org/0000-0002-5905-2783

María Cecilia Ávila-Portuanto

Universidad Católica del Norte

Antofagasta, Chile

mavila@ucn.cl

https://orcid.org/0000-0002-7667-7339

Recibido • Received • Recebido: 03 / 08 / 2019

Corregido • Revised • Revisado: 19/03 / 2021

Aceptado • Accepted • Aprovado: 08 / 04 / 2021

\begin{abstract}
This essay focuses on a description of the complexities of Prepositional Phrases (PPs) and their challenges for EFL learners. The rationale is to raise language awareness of the multifaceted nature of the PP in teachers and students. The grammatical explanations offered in the literature review are based on Functional Grammar. Moreover, previous research conducted addressing the issues of EFL learners facing problems with PPs are proposed in four configurations: semantic, syntactic, lexical and socio-cultural. Such configurations address scenarios for the identification of multiple meanings, different syntactic functions and structures, regional variations, typology, formal and informal language usage, among others, which represent obstacles and difficulties in the comprehension of the topic by EFL learners. Finally, we conclude that the limited use of syntactic functions, poor internal configuration of PPs, as well as the high frequency of errors reported by previous research indicate PPs are complex to use. Thereby, explicitly reinforcing the teaching of all the configurations of PPs is suggested.
\end{abstract}

Keywords: EFL learners; functional grammar; prepositional phrases. 
http://doi.org/10.15359/ree.25-2.29

http://www.una.ac.cr/educare

educare@una.ac.cr

Resumen: Este ensayo ofrece una descripción general de las complejidades típicas de las frases preposicionales y los desafíos que estas representan para aprendientes del inglés como lengua extranjera. El propósito es despertar, en estudiantes y docentes, la conciencia lingüística sobre la naturaleza multifacética de la frase preposicional. El soporte teórico está fundamentado en la gramática funcional. La reflexión se construye a partir de una revisión de investigaciones anteriores que han tratado los problemas que enfrentan estudiantes del inglés como lengua extranjera durante el aprendizaje de las frases preposicionales. Esta revisión permitió categorizar dichas complejidades en cuatro configuraciones: semántica, sintáctica, léxica y socio-cultural. A partir de ellas se generan una serie de dificultades relacionadas con los múltiples significados de las frases preposicionales, sus funciones y configuraciones sintácticas, las variantes regionales, tipologías, registro formal e informal del lenguaje, entre otros, que obstaculizan la comprensión del tópico. Para cada una de estas configuraciones, se ofrece una explicación amplia desde la gramática funcional. Finalmente, creemos que el uso limitado de las funciones sintácticas, una configuración pobre de la estructura interna, así como un alto porcentaje de errores registrados en las investigaciones previas definitivamente hacen de la frase preposicional una estructura compleja de utilizar. Por lo tanto, sugerimos una enseñanza explícita de todas estas configuraciones.

Palabras claves: Estudiantes del inglés como lengua extranjera; frases preposicionales; gramática funcional.

Resumo: Este ensaio fornece uma descrição geral das complexidades típicas de frases preposicionais e os desafios que representam para estudantes de inglês como língua estrangeira. O objetivo é despertar, tanto em estudantes como em professores, a consciência lingüística sobre a natureza multifacetada da frase preposicional. O suporte teórico é baseado na Gramática Funcional. A reflexão é construída a partir de uma revisão de pesquisas anteriores que abordaram os problemas enfrentados por estudantes de inglês como língua estrangeira enquanto aprendiam frases preposicionais. Esta revisão permitiu categorizar essas complexidades em quatro configurações: semântica, sintática, lexical e sociocultural. A partir delas, gera-se uma série de dificuldades relacionadas aos múltiplos sentidos das frases preposicionais, suas funções e configurações sintáticas, variantes regionais, tipologias, registro formal e informal da linguagem, entre outros, que dificultam a compreensão do tema. Para cada uma dessas configurações, uma explicação ampla é oferecida a partir da Gramática Funcional. Finalmente, acreditamos que o uso limitado de funções sintáticas, uma configuração pobre da estrutura interna, bem como um alto percentual de erros registrados em investigações anteriores definitivamente tornam a expressão preposicional uma estrutura complexa a ser usada. Portanto, sugerimos um ensino explícito de todas essas configurações.

Palavras-chave: Estudantes de inglês como língua estrangeira; frases preposicionais; gramática funcional.

\section{Introduction}

In the field of ELT, prepositions in the context of a Prepositional Phrase (PP) have always been a topic of great interest for researchers and practitioners. As a result of their linguistic complexity, they have been studied from different theoretical perspectives throughout the years (Biber et al., 1999; Downing, \& Locke, 2006; Halliday, \& Matthiessen, 2014; Huddleston, \& 
Pullum, 2002; Quirk et al., 1985; Schisbye, 1957). Some authors believe that such complexity is generally attributable to their multiple meanings, different syntactic functions and structures, regional variations, typology, formal and informal language usage, among others (Bakka, 2015; Benelhadj, 2015; Chodorow et al., 2007; Đorđević, 2013).

Despite a plethora of information produced on the subject matter, PPs continue to be an obstacle for EFL learners and teachers.

In this paper, we mainly focus on three tasks: 1. compile a description of those aspects which make PPs challenging in the learning/teaching paradigm, 2. provide a theoretical background in understanding the logic behind such difficulties from a broadly functional grammar perspective, and 3. offer a general insight for a functional grammar perspective to teach PPs. Our intention is not to suggest that teachers teach functional grammar to EFL students, but rather gently segue into highlighting the existences of additional dimensions such as culture, usage, and functions when explaining PPs and their usage in commonplace language. Thus, the ultimate purpose is to raise language awareness of the multifaceted nature of the PP so that teachers and students develop, as expressed by Carter (2003), "an enhanced consciousness of and sensitivity to the forms and functions of language" (p. 64). Although this study might not be enough to overcome all the problems PPs generate in language instruction and learning, it is believed to be a step in consolidating a more comprehensive view of the topic.

\section{Literature Review}

Halliday, \& Matthiessen (2014) point out that a PP "consists of a preposition plus a nominal group" (p. 424). The following utterance illustrates this point:

\section{She was hiding under the table (Davies, 2008)}

In 1, the relationship between the preposition under and the nominal group the table is necessary. Although the preposition reveals the location of the subject she, the meaning of the sentence is more complete because of the specification introduced by the nominal group. This inevitable marriage between preposition and its complement is called prepositional phrase (PP). Downing and Locke (2006) point out, "And where there is a preposition there is a PP, since prepositions cannot normally stand alone" (pp. 531-532).

Regarding its syntactic function, Halliday, \& Matthiessen (2014) claim that the PP serves as adjunct in the modal structure of the clause and that this adjunct can be:

- circumstantial adjuncts, indicating spatial and temporal reference as it is shown in 2:

2. This man is a doctor and has to be at the hospital in the morning; (Davies, 2008) 
http://doi.org/10.15359/ree.25-2.29

http://www.una.ac.cr/educare

educare@una.ac.cr

- stance adjuncts (interpersonal), through which a personal and social relationships can be expressed as in 3:

3. ...it reflects, in my opinion, a very serious trend in America of not taking journalism seriously...) (Davies, 2008)

- connective adjuncts (conjunctive), serving as a link among utterances in the discourse as in example 4:

4. ONAN: Thursday. Will you be ready to go up on Thursday afternoon, Neomi?

Prof. NEOMI RAO: My understanding from the staff is that they would like to wrap up Thursday evening if possible.

CONAN: Well, in that case, I sit corrected. Thank you very much for your time. (Davies, 2008)

In addition, it can be embedded in another group, serving as post-modifier of a noun as illustrated in 5:

5. She would read him that book with the animal noises..., (Davies, 2008) or as postmodifier of an adverb as 6 shows:

6. This goes far beyond himself and his political career... (Davies, 2008)

\section{The Complex Configuration of the PP}

This section will broadly display these configurations, and their impact in the learning process will be considered.

\section{Semantic Configuration}

Semantically, PPs are said to have two complications: an assortment of adverbial meanings (circumstances) and the polysemous characteristic of prepositions (Đorđević, 2013). Both complications are related to the two types of meanings implied in prepositions: grammaticised or bound and lexical or free (Downing, \& Locke, 2006).

Lexical Prepositions

Lexical prepositions are free. Their choice will depend on the speaker's intention; therefore, their meaning varies.

In general, functional grammar distinguishes four different meanings for lexical prepositions: location in space, time relations, metaphorical and abstract uses, and non-locative meanings which basically refer to other types of circumstance. 


\section{Location in Space}

Location has to do with a mental representation of the spatial relationship between two elements based on the principle of prominence in which a Figure, projecting or moving towards any direction, reaches for a Ground or supporting surface. This representation comprises three references:

- A point in space as in He is still at the post office rapping. (Davies, 2008)

- In contact with a surface as in Powel sat on a bench at the edge of the crowded playground. (Davies, 2008)

- Containment as in He was in a classroom full of children at the time. (Davies, 2008)

A point in space implies a vague reference of the location of the Figure He in relation to the Ground. He could actually be stationed somewhere at the post office without specification of the exact location; that is, inside the post office, outside the post office, on the corner of the post office, among other possible locations.

In contact with a surface refers to actual contact in which the Figure touches the Ground whether horizontally or vertically.

Containment denotes enclosing where the Figure somehow is located partially or completely within an area that serves as the Ground.

In the previous three cases, location refers to a stationary condition of the Figure with respect to the Ground; however, this relationship is not always static. When the Figure moves towards the Ground, a change of location is expressed. Such change implies any movement from a point $A$ (source) to a point $B$ (goal). Some of the most common prepositions serving this purpose are across, along, through, past as illustrated in 7:

7. They need to walk across the campus to put a nickel in the meter. (Davies, 2008)

Some prepositions work correlatively to express movement. In this group we find: from... to; off...onto; off...into, as shown by 8 :

8. I swipe crumbs off my lap and onto the rug. (Davies, 2008)

Location also includes other spatial prepositions whose meanings are different from reference, contact, containment and movement as shown in Table 1. 
http://doi.org/10.15359/ree.25-2.29

http://www.una.ac.cr/educare

educare@una.ac.cr

Table 1: Other Spatial Prepositions

\begin{tabular}{lll}
\hline Spatial Meanings & Prepositions & Examples \\
\hline High(er) or low(er) position & over / under & 9. The B-36s flew over our house. (Davies, 2008) \\
Circular movement & around / round & 10. she ran circles around him... (Davies, 2008-) \\
Degrees of proximity & next to, by & 11. I get to work next to the castle. (Davies, 2008) \\
Agency & By & 12. The second was a play by Shakespeare. (Davies, 2008) \\
\hline Relative position & between, among & 13. Paramedics moved between the cars... (Davies, 2008) \\
\hline
\end{tabular}

Note: Self-generated

\section{Time Relations}

Prepositions, including those expressing location in space, also express ideas related to circumstances of time. Figure 1 summarizes these cases.

Figure 1: Time Relations

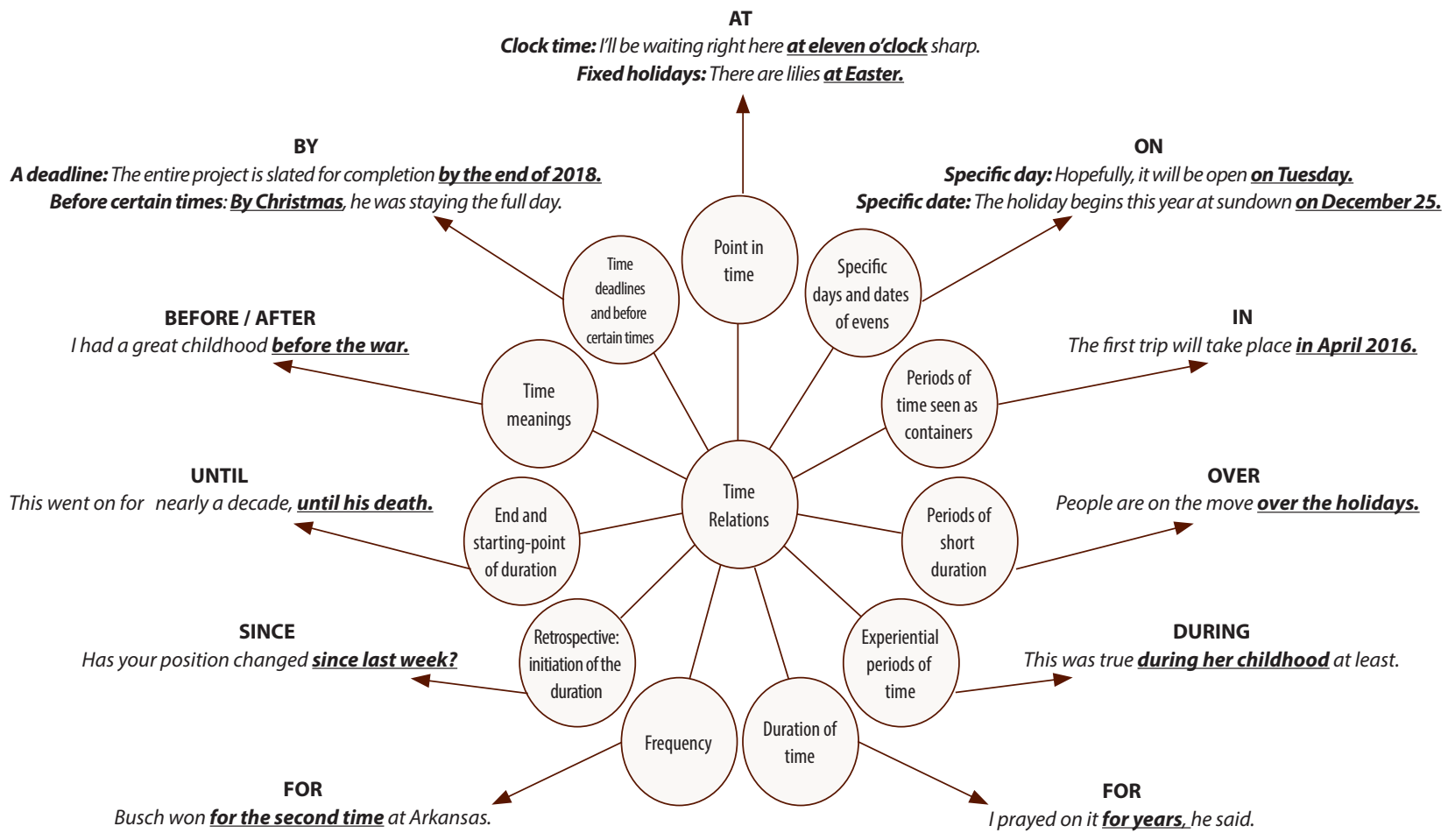

Note: Self-generated with examples taken from (Davies, 2008). 
As shown in Figure 1, there are as many temporal and spatial meanings as circumstances naturally occurring in the English language. In this respect, Ponmani and Mekla (2015) claim, "In English, there are almost 100 prepositions attributed to multiple meanings. The meaning of prepositions varies according to the context" (p. 26). The following examples illustrate this point:

14. ...her son Manolo was right by her side... (Davies, 2008)

15. Anita's children are being raised by her first husband (Davies, 2008)

In 14, the PP by her side shows a degree of proximity of spatial location; that is, it is indicating where the subject her son Manolo is. In 15, the meaning of the PP by her first husband reveals the function of agency; that is, who is responsible for Anita's children's rising. As it is observed, the context provides different roles and meanings for the by PP. Ponmani and Mekla (2015) point out EFL students are not aware of such semantic relationships between the PP and the context. Therefore, they might struggle to figure out, on the one hand, the meaning of the by PP in different contexts and, on the other, what meaning they should assign to it when speaking or writing.

Although circumstances of time and place might be considered of a minor problem since they are easily revealed by a question: when, how often, or where, other cases such as metaphorical and abstract uses apparently pose a major difficulty to EFL learners for they are harder to identify and define.

\section{Metaphorical and Abstract Uses}

Temporal and spatial location as described previously refer to circumstantial meanings, one of the syntactic functions of PPs as adjuncts. Metaphorical and abstract uses not only make reference to circumstantial meanings, but also add two other functions: interpersonal and conjunctive meanings as extra ingredients. As a result, a substantial complication in the comprehension and use of PPs is realized.

Another example of metaphorical and abstract use is described by Downing and Locke (2006) who include in this list the prepositions between, into, over, under, out of, on, off, up, down, through, and with. Obviously, this is not intended to be a complete list, but merely some examples of metaphorical and abstract uses. Figure 2 shows examples of some of these cases. 
http://doi.org/10.15359/ree.25-2.29

http://www.una.ac.cr/educare

educare@una.ac.cr

Figure 2: Metaphorical and abstract uses of between, into, over/under
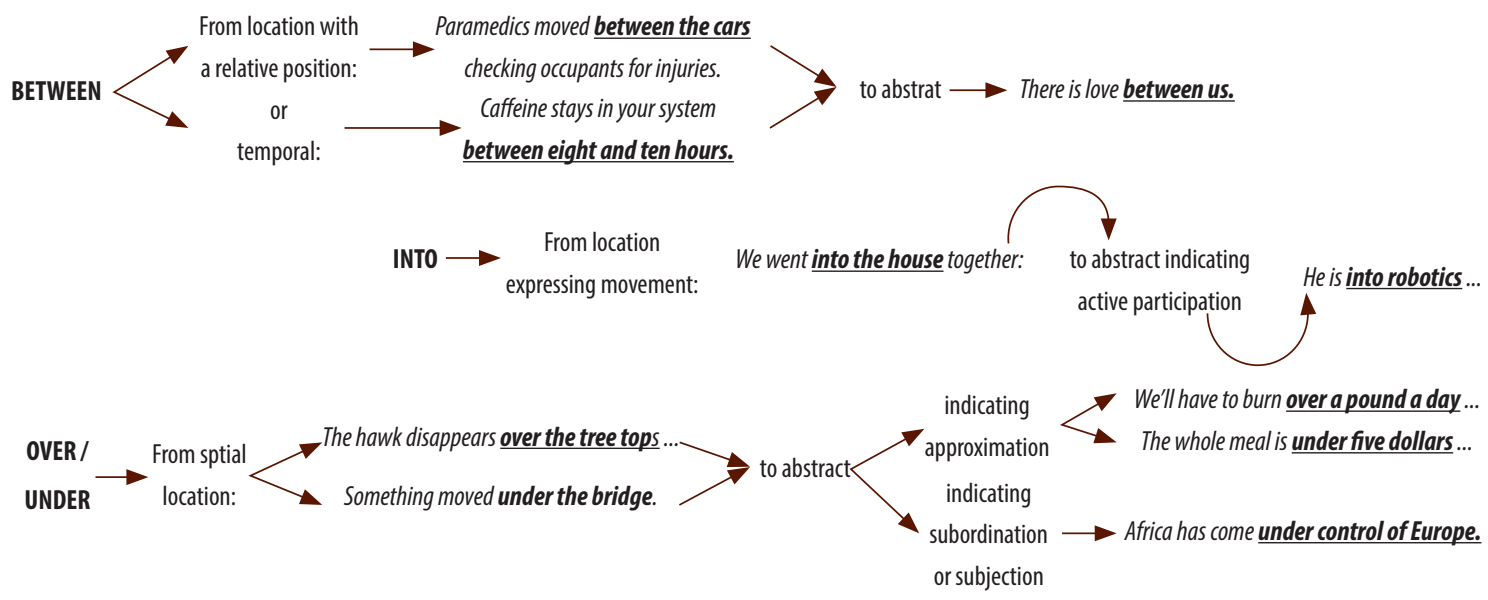

Note: Self-generated with examples taken from (Davies, 2008).

As previously mentioned, the uses of metaphorical and abstract PPs can be complicated to understand and grasp. Confusion takes place when the same preposition has a literal meaning and a metaphorical one as declared by Sinmisola Sotiloye et al. (2015):

Other evidences that show the troublesome nature of the English preposition are the changes posed by change in meaning of preposition in special usage. The learner has to contend with plain (literal) meanings of prepositions as against when used in idiomatic expressions. (p. 105)

Examples 16 and 17 show this case:

16. -DAREN-BEAUMONT: The house is on fire.

-911 OPERATOR: Is everybody out of the house?

—DAREN-BEAUMONT: I don't know. But it's on fire really strongly. (Davies, 2008)

17. What's truly amazing is after 13 years on the air this show is still on fire.

Both examples come from TV programs, in 16 on fire expresses a temporary condition; that is, the house is being consumed by fire at the moment of the report. In 17, on the contrary, the meaning is metaphorical. This implies that after being on the air for so long, the show is still very popular among the audience. Although both examples refer to a temporary condition, the meaning in 17 is that of success in a row, to be doing great and having no need to stop. This type of semantic problem is linked to idiomatic meaning implied in culture. 
To Flores Galleguillos (2013), the problem with prepositions appears to focus more on the abstract use. In her study, part of her results showed identifying abstract usage of prepositions on and at represents the biggest problem for students, in contrast with concrete usage (spatial and temporal) of the same prepositions.

Sinmisola Sotiloye, et al. (2015) also confirmed this position. In their research, results showed $82,3 \%$ of the sample failed in identifying the metaphorical use of prepositions on, at and for in context, determining this was one of the main sources of problems in the sample studied.

Non-locative meanings or other types of circumstances

The prepositions in this group refer to other types of circumstances or ideas that do not fit any of the cases described thus far. Some of them are, for, like, as, in, with and without. See Table 2.

Table 2: Other Types of Circumstances

\begin{tabular}{ll}
\hline Circumstance & Examples \\
\hline Purpose & 18. All participants needed to use speech for communication. (Davies, 2008) \\
Intended destination & 19. Then it was over, and we were heading for the river. (Davies, 2008) \\
Similarity & 20. He cuts through the water like a boat. (Davies, 2008) \\
Roles, jobs, functions & 21. Jerry Brown worked as a teacher in Caldwell County... (Davies, 2008) \\
Accompaniment & 22. Jeremy was coming down the hill with his friend, Dan... (Davies, 2008) \\
Possession & 23. His scull is loaded with his possessions... (Davies, 2008) \\
Part-whole relationship & 24. I want to live in a house with a garden. (Davies, 2008) \\
Instrument & 25.I have been hit with a baseball bat. (Davies, 2008) \\
Condition & 26. I left the house in a hurry. (Davies, 2008) \\
Reason & 27. Our local women are known for their beauty. (Davies, 2008)
\end{tabular}

Note: Self-generated

The meaning in these non-locative PPs seems to be literal rather than metaphorical which apparently entails fewer complications for learners as already explained.

\section{Grammaticised Prepositions}

One last aspect regarding the semantic configuration of PPs is, the grammaticised or bound prepositions. Downing and Locke (2006) point out grammaticised prepositions appear in collocation and have, with a few exceptions, a fixed meaning determined by a noun (Will 
http://doi.org/10.15359/ree.25-2.29

http://www.una.ac.cr/educare

educare@una.ac.cr

there ever be a cure for cancer?), an adjective (We are not afraid of accountability), or a verb (We often forget about that). Many cases of prepositions preceded by a verb fall into the category of phrasal verbs such as put up. Those specific cases of prepositions will also be considered in this study even when they constitute, along with the verb, a different part of speech; or lose their full original lexical meaning as it is shown in 28 :

28. If you put up a fight you'll be out of business. (Davies, 2008)

\section{Syntactic Configuration}

The complexity here lies mainly on the syntactic structure (internal configuration) and syntactic functions (roles in and within a clause) of the PP. Downing and Locke (2006) point out fourteen syntactic functions divided in three groups:

PPs as Functions

There two functions: locative complement, shown in 29, and goal complement, shown in 30.

29. The train to London is now standing at the platform (Downing, \& Locke, 2006)

30. The high-speed train from York is drawing into the station (Downing, \& Locke, 2006)

PPs as Elements of Clauses

PPs represent up to five constituent roles in a clause. Examples 31 through to 35 show each case. See Table 3.

Table 3: PPs as Elements of Clauses

\begin{tabular}{ll}
\hline Elements of Clauses & Examples \\
\hline Subject & 31. After dark is the only good time for fireworks. (Downing, \& Locke, 2006) \\
Direct Object & 32. I don't consider next to a railway line a good place to live. (Davies, 2008) \\
Prepositional Object & 33. Was someone tampering with the GPS? (Davies, 2008) \\
Subject Complement & 34. She is out of her mind to be joking about these types of things. (Davies, 2008) \\
Object Complement & 35. His illness left him without a job. (Downing, \& Locke, 2006) \\
\hline
\end{tabular}

Note: Self-generated 
http://doi.org/10.15359/ree.25-2.29

\section{PPs embedded as Elements of Groups}

In this case, PPs do not have an independent position in the clause; they are subordinated to a group. See Table 4.

Table 4: PPs Embedded as Elements of Clauses

\begin{tabular}{ll}
\hline Elements of Clauses & Examples \\
\hline Post-modifier in a Nominal Group & 36. A small house on the hill. (Davies, 2008) \\
Complement in a Nominal Group & 37. Prince is a teacher of French... (Davies, 2008) \\
Pre-modifier in a Nominal Group & 38. And that's my off the record comment tonight. (Davies, 2008) \\
Complement in an Adjectival Group & 39. She is very brilliant at baffling. (Davies, 2008) \\
Complement in an Adverbial Group & 40. My home is not far from here... (Davies, 2008-) \\
Complement in a PP & 41. Conrad hadn't seen the place, [except (on TV)]... (Davies, 2008) \\
Embedded in another PP & 42. He was [on the way (to healthcare)]. (Davies, 2008) \\
\hline
\end{tabular}

Note: Self-generated

The syntactic structure of PPs (internal configuration) is another complexity. In a PP the structure is generally composed of a preposition and the prepositional complement. This complement varies and such variation represents the real problem. Downing and Locke (2006) establish seven different types of prepositional complements shown in Table 5.

Table 5: Syntactic Structure of PPs

\begin{tabular}{ll}
\hline Prepositional Complements & Examples \\
\hline Nominal Group & 43. I hope you are playing at home. (Davies, 2008) \\
Adjectival Group & 44. He asked to speak to me out in private. (Davies, 2008) \\
Adverbial Group & 45. I am cautiously optimistic for now. (Davies, 2008) \\
Prepositional Phrase & 46. Ted Turner called from [out of the blue]. (Davies, 2008) \\
Wh-clause + finite verb & 47. I became much more pointed about what I was saying. (Davies, 2008) \\
Wh-clause + infinitive verb & 48. We asked him for advice on what to write. (Davies, 2008) \\
Wh-clause + gerund verb & 49. There are no challenges with working with kids. (Davies, 2008) \\
\hline
\end{tabular}

Note: Self-generated 
http://doi.org/10.15359/ree.25-2.29

http://www.una.ac.cr/educare

educare@una.ac.cr

Although studies about errors in the use of prepositions do not focus on syntactic elements as the ones described in the syntactic configuration section, we presume that being unaware of such functions might generate some confusion regarding the position or specific functions that PPs may have in the sentence. In fact, authors like Đorđević (2013) insist that, "The most common cause of difficulties is that many prepositions perform a number of complex syntactic roles. Unlike other words, prepositions have several syntactic functions which can also be demanding for learners" (p. 25).

Such unawareness may also result in a poor internal structure of the prepositional complement as suggested by Keith et al. (2016). In their research, the authors pointed out that students are more aware of the syntactic functions of an adjunct as a constituent in a sentence than with other functions. Regarding PPs embedded in a clause, results show a tendency towards less complex cases (post-modifier or complement of the head in a nominal group). The same happens for the syntactic structure of PPs, highly favoring the nominal group as the prepositional complement. In addition to these findings, there is also a high percentage of errors in the use of PPs.

The authors concluded, on the one hand, that the high percentage of errors reveals a great difficulty in EFL learners' production of PPs; on the other, that using less complex syntactic functions and a limited internal configuration of PPs shows students' lack of knowledge of the topic.

\section{Lexical Configuration}

This type of complexity may have to do with the learner's lexical options or combinations of prepositions in the context of a PP. Prepositions can be single or compound (multi-word prepositions) (Benelhadj, 2015; Đorđević, 2013; Downing, \& Locke, 2006). Single prepositions consist of only one word as in before, after; whereas compound prepositions, on the contrary, are formed by two or more words such as in spite of, next to, as shown in 50 and 51:

50.There were only a few streets where it was safe to wander around [after] dark. (Davies, 2008)

51. We are a complex people [because of] our historical experience. (Davies, 2008)

Research specifically addressing the topic of difficulty with compound prepositions in language learning/teaching contexts is rather scarce, not to say inexistent. The few papers found on multi-word prepositions problems are outdated and related to other fields different from teaching such as translation (Sigurd, 1993). Most T/EFL studies focus on general problems with prepositions such as omission, addition, disordering, misformation, neglecting the type of problems or difficulties generated by compound prepositions in EFL learners. In their study, Keith et al. (2016) do mention however, that out of 598 examples of prepositions used by 
students, only 12 examples (2\%) constituted compound prepositions ( 10 examples of because of, 1 example of instead of and 1 example of out of respectively). The authors attributed this low frequency to students' lack of knowledge of the topic.

\section{Socio-cultural Configuration}

This configuration is linked, on the one hand, to regional variations and social classes and, on the other, to different registers. Regarding regional variation and social classes, Đorđević (2013) point out the differences between American and British English in the use of the preposition of time at. While Britons say at the weekend, Americans express the same idea with the preposition on as in on the weekend.

The same author considers these configurations to be challenging due to the extensive availability of lexical repertoire in cultural communicative events. This bundle of differences rooted in the English language culture is not easily grasped by the EFL learner who is generally instructed in a non-English speaking country.

The complex considerations of the use of PPs offered in this study may be insightful for teachers and practitioners to have a better understanding of the multifaceted uses of PPs, and how their configurations represent an obstacle or a major challenge for EFL students.

\section{Why Functional Grammar}

As described in the previous sections, the complexity of PPs is evident. A traditional approach to teaching grammar is still prevalent in most educational systems. Unfortunately, said approach mainly focuses on the instruction of "... isolated linguistic features such as the eight parts of speech and sentence types. This type of instruction omits an important part of writing which is the interrelatedness between grammar structures and meaning" (Aguirre-Muñoz et al., 2015, p. 1). Since language is social rather than biologically-oriented (Martin et al., 1997), approaching PPs from a perspective where a speakers' social and cultural context, as well as, their interactions are considered, may serve to illuminate the issue for a better understanding of the problem. Consequently, we turn to functional grammar as it discloses how grammar is used in social interactions.

Using the metafunctions (ideational, interpersonal and textual) to augment the teaching of PPs, as suggested by previous research (Aguirre-Muñoz et al. 2015; AlHamdany, 2012; Ali et al., 2017; Derewianka, \& Jones, 2010; Feng, 2013; Schleppegrell, 2004), might elucidate the complexities of PPs. Thus, giving EFL students a better insight into syntactic functions and structures of PPs which pose a complex configuration that affects learners' understanding of the topic. 
http://doi.org/10.15359/ree.25-2.29

http://www.una.ac.cr/educare

educare@una.ac.cr

In order to improve the teaching of PPs at a university level, we propose a pedagogical approach strategy comprising three phases: 1. rising students' awareness of the metafunctions of language, 2. interrelating grammar structures, meaning and culture from a descriptive perspective, and 3. guiding the oral and written production of PPs.

\section{Phase 1: Rising Students' Awareness of Metafunctions}

The metafunctions (ideational, interpersonal and textual) are introduced here. Its purpose is to include a different perspective in the understanding of language as a whole, stretching the boundaries of language further than that of isolated syntactic structures.

\section{Phase 2: Interrelating Grammar Structures, Meaning and Culture}

Under the scope of Functional Grammar, complementing nouns, adjectives, verbs, and adverbs is the first role of PPs students perceive in context; therefore, meaning and culture should be given priority in instruction. Rather than teaching complex syntactic features and varied lexical options in isolation, instruction of PPs should be approached as a semantic mechanism of the English culture to amplify meaning. This task should be done by showing patterns of language, backed up with a descriptive process of analysis. This descriptive analysis shows students the tendencies; tendencies lead to generalizations and generalizations reveal patterns. The ultimate goal is to understand how the amplification of meaning is construed in a different culture by means of identified and clear cut PPs patterns so that they can be assimilated and used by students.

This phase is based on the ideational and interpersonal metafunctions. The first one is concerned with our interpretation of the world; the way we see it or experience it. The way we express, through language, our perception of the world is intrinsically connected to culture and society. It is about construing the world through language. The interpersonal metafunction deals with the interaction of speakers and the situations for that interaction; that is, how we express our position; our stance under specific circumstances; how we express our attitude to others. It is about enacting who we are, what we think through language and conveying that to others.

\section{Phase 3: Guiding the Oral and Written Production of PPs}

Once students have understood how meaning is amplified via PPs, a descriptive analysis can be used to identify syntactic and lexical patterns that match with their corresponding meanings. This phase becomes the scenario to crystalize meanings; that is, the way we construe the world (ideational) and the way we communicate our thoughts (interpersonal) turn into actual forms of language (textual). The syntactic configuration of PPs is therefore located within the territory of the textual metafunctions. This metafunction has to do with the platform where construing our experience coherently and enacting ourselves through language cohesively are instantiated. 
By becoming aware of the metafunctional characteristics of PPs, the seasoned EL teacher can incorporate them into their pedagogical strategies to provide a deeper understanding of the use of PPs in different linguistic configurations.

\section{Concluding Remarks}

This essay has described the complex configurations of PPs from a Functional Grammar perspective, and how such configurations constitute a problem for EFL learners generating, among others, errors in the syntactic functions of PPs, a poor internal configuration of the syntactic structure, a tendency to neglect the use of compound prepositions in the PP, as well as a continuous confusion regarding metaphorical, abstract and literal meanings. With this in mind, we venture to suggest that PPs be taught in depth, scaffolding their usage throughout an EFL program at the university level. It is important to highlight that all aspects of the PP should be considered: syntactic configurations and functions, semantic elasticity and pragmatic functions.

Far from offering teaching tips to address the issue, we advise starting from the beginning: knowing the nature of the problem. Being aware of commonplace language combinations and complications brought about by the production of PPs may prepare teachers to plan their instruction in a more systematic manner, teaching known peculiarities of the topic. Understanding the root of the conundrum may facilitate instruction and comprehension, eventually leading to increased language performance.

\section{Supplementary Material Statement}

This article has a preprint version available at https://doi.org/10.5281/zenodo.4041853

\section{References}

Aguirre-Muñoz, Z., Chang, R., \& Sanders, J. (2015). Functional grammar instruction impact on writing quality. Educational Polices and Current Practices, 1(2), 71-85. https://doi. org/10.15340/2147350112847

AlHamdany, H. (2012). The usefulness of systemic functional grammar and its impact on students' communicative skills in ESL context. European Scientific Journal, 8(11), 176-194. https://doi.org/10.19044/esj.2012.v8n11p\%25p

Ali, Q., Mustafa, M., Maqbool, I., Imam, F., Tahira, M., \& NaaZ, A. (2017). Role of functional grammar in teaching and learning English. WALIA Journal, 33(1), 81-83. http://waliaj.com/ wp-content/2017/Issue\%201,\%202017/13w.pdf 
http://doi.org/10.15359/ree.25-2.29

http://www.una.ac.cr/educare

educare@una.ac.cr

Bakka, V. (2015). Overcoming difficulties in learning prepositions. International Journal of English Language, Literature and Translation Studies, 2(2), 239-241. http://www.ijelr. in/2.2.15/239-\%20241\%20VINOD\%20BAKKA.pdf

Benelhadj, F. (2015). Prepositional phrases across disciplines and research genres: A syntactic and semantic approach [Doctoral degree]. University of Sfax, Tunisia. http://www.isfla.org/ Systemics/Print/Theses/FatmaBenelhadjPhDThesis.pdf

Biber, D., Johansson, S., Leech, G., Conrad, S., \& Finegan, E. (1999). Longman grammar of spoken and written English. Longman.

Carter, R. (2003). Language awareness. ELT Journal, 57(1), 64-65. https://doi.org/10.1093/ elt/57.1.64

Chodorow, M., Tetreault, J. R., \& Han, N-R. (2007). Detection of grammatical errors involving prepositions. In F. Costello, J. Kelleher, \& M. Volk (Ed.), Proceedings of the 4th ACL-SIGSEM. Workshop on Prepositions (pp. 25-30). Asociación de Lingüística Computacional. https:// doi.org/10.3115/1654629.1654635

Davies, M. (2008). The corpus of contemporary American English (COCA): 560 million words, 1990-present. https://corpus.byu.edu/coca/.

Derewianka, B., \& Jones, P. (2010). From traditional grammar to functional grammar: Bridging the divide. NALDIC Quarterly, 8(1), 6-17. https://ro.uow.edu.au/cgi/viewcontent.cgi?article $=2000 \&$ context $=$ sspapers

Đorđević, M. (2013). Typical difficulties in English for Serbian learners. CIVITAS, 5, 24-34. https:// www.ceeol.com/search/article-detail?id=766641

Downing, A., \& Locke, P. (2006). English grammar. A university course $\left(2^{\text {nd }}\right.$ ed.). Routledge. https:// doi.org/10.4324/9780203087640

Feng, Z. (2013). Functional grammar and its implications for English teaching and learning. English Language Teaching, 6(10), 86-94. https://doi.org/10.5539/elt.v6n10p86

Flores Galleguillos, C. (2013). The acquisition of English prepositions among Chilean EFL learners [Master Thesis]. Universidad de Chile. http://www.repositorio.uchile.cl/ handle/2250/115654

Halliday, M.A.K., \& Matthiessen, C. (M. I. M. 2014). Halliday's introduction to functional grammar (Revised by C. M. I. M. Matthiessen, 4th ed.). Routledge.

Huddleston, R., \& Pullum, G. K. (2002). The Cambridge grammar of the English language. Cambridge University Press. https://doi.org/10.1017/9781316423530 
http://doi.org/10.15359/ree.25-2.29

http://www.una.ac.cr/educare educare@una.ac.cr

Keith, H., Trigo, I., \& Urrutia, Y. (2016). Uso de las frases preposicionales en el discurso oral de estudiantes de inglés [Tesis de licenciatura inédita]. Universidad Católica del Norte, Antofagasta, Chile.

Martin, J. R., Matthiessen, C. M. I. M., \& Painter, C. (1997). Working with functional grammar. Arnold.

Ponmani, M., \& Mekla, S. (2015). The role of semantic functions in learning English prepositions. A Journal of Teaching English Language and Literature, 31. http://www.fortell.org/content/ role-semantic-functions-learning-english-prepositions

Quirk, R., Greenbaum, S., Leech, G., \& Svartvik, J. (1985). A comprehensive grammar of the English language. Longman.

Schibsbye, K. (1957). A modern English grammar. Oxford University Press.

Schleppegrell, M. J. (2004). The language of schooling: A functional linguistics perspective. Lawrence Erlbaum Associates. https://doi.org/10.4324/9781410610317

Sigurd, B. (1993). The problems with multi-word prepositions and subjunctions. Working Papers, 40, 197-212. https://journals.lub.lu.se/LWPL/article/view/2513/2088

Sinmisola Sotiloye, B., Bodunde, H., \& Olayemi, O. (2015). English language prepositions: An albatross for English language learners in Nigeria. International Journal of English and Literature, 6(6), 103-108. https://doi.org/10.5897/IJEL2015.0783 